\title{
O PIBID e a aprendizagem significativa no ensino de Filosofia: um relato de experiência
}

\author{
The PIBID and the meaningful learning in the philosophy teaching: an experience \\ report
}

\section{Felipe Barreto Santana}

Professor no Complexo Educacional Taboão da Serra, Taboão da Serra, São Paulo, Brasil. felipesantana.tmx@gmail.com

\section{Angela Zamora Cilento}

Professora na Universidade Presbiteriana Mackenzie, São Paulo, São Paulo, Brasil. angelazamoracilento@gmail.com

Recebido em 30 de novembro de 2017

Aprovado em 10 de maio de 2018

Publicado em 17 de agosto de 2018

RESUMO: Objetivamos no presente artigo refletir sobre o programa PIBID/Filosofia/Mackenzie como instrumento de promoção da aprendizagem significativa. Pautaremos nossas discussões sobre o conceito de aprendizagem significativa e, posteriormente no levantamento do histórico e dos objetivos do Projeto e nas suas aplicações, comentando sobre as suas potencialidades bem como na experiência proveniente de um ex-bolsista e hoje, docente.

Palavras-chave: Aprendizagem significativa, PIBID/Filosofia/Mackenzie, ensino de filosofia.

ABSTRACT: We aim in this article to reflect on the PIBID / Philosophy / Mackenzie program as a tool to promote meaningful learning. We will discuss our discussions about the concept of meaningful learning and later on the history and objectives of the Project and its applications, commenting on its potential as well as the experience of a former scholarship student and teacher.

Keywords: Meaningful learning, PIBID/Philosophy/ Mackenzie, philosophy teaching.

\section{Introdução}

Nosso trabalho objetiva discorrer sobre o Programa de Iniciação à Docência - PIBID que teve origem há 10 anos e tem sido até o presente momento, um agente motivador de constante aperfeiçoamento na formação dos licenciandos diretamente envolvidos com o 
programa. Na primeira parte do nosso trabalho, apresentamos o histórico e os objetivos do PIBID. Relataremos a trajetória do programa desde sua criação, até a implementação junto ao curso de licenciatura em filosofia da Universidade Presbiteriana Mackenzie. Posteriormente, nos dedicamos na busca de uma definição clara e distinta acerca do conceito de "Aprendizagem Significativa". A partir da perspectiva de Ausubel, Rogers e Coll, estabeleceremos uma reflexão sobre o conceito em questão. A terceira parte tratará da relação entre o PIBID e o conceito de aprendizagem significativa, e neste trabalho a dividimos em quatro tópicos. Partiremos da apresentação das ações previstas do programa PIBID/Filosofia - Mackenzie. Em seguida, relataremos os impactos do programa para os alunos do ensino médio participantes, através da exposição de produções realizadas pelos mesmos e mediadas pelos pibidianos. Subsequentemente, as produções acadêmicas relacionadas ao PIBID, oriundas dos bolsistas, foram os nossos objetos de análise. O último tópico se destinará a apresentação do relato de experiência de um ex-pibidiano e hoje docente.

Acreditamos que este trabalho tem o mérito de expor esta trajetória do PIBID em nossa Instituição, bem como a de lançar luzes para o ensino de filosofia - disciplina com um alto teor de abstração e que requer, como tudo aquilo que busca a excelência, constante aprimoramento no que tange à possíveis metodologias articuladas ao arsenal teórico. Além disso, pretende resgatar as intervenções que foram realizadas nas escolas parceiras durante este período que geraram bons resultados, durante os anos de 2015 e 2016, na aplicação do projeto PIBID/FILOSOFIA/MACKENZIE.

\section{O projeto PIBID: objetivos e trajetória}

$\mathrm{Na}$ pretensão de promover a iniciação à docência de discentes de instituições de educação superior dos cursos de licenciatura, o Programa Institucional de Bolsa de Iniciação à Docência (PIBID) foi criado no ano de 2007 . Fruto de uma ação conjunta do Ministério da Educação, por intermédio da Secretaria de Educação Superior - SESu, da Fundação Coordenação de Aperfeiçoamento de Pessoal de Nível Superior - CAPES, e do Fundo Nacional de Desenvolvimento da Educação - FNDE.

O seu primeiro edital, publicado em 12 de dezembro de 2007, foi destinado unicamente a Instituições Federais de Ensino Superior - IFES. Nesta publicação, foi priorizada a formação de docentes para atuar nas seguintes áreas do conhecimento e níveis de ensino, nesta ordem: para o ensino médio: licenciatura em física, licenciatura em química, licenciatura em matemática e licenciatura em biologia; para o ensino médio e para os anos finais do ensino fundamental: licenciatura em ciências e licenciatura em matemática; de forma complementar: licenciatura em letras (língua portuguesa), licenciatura em educação musical e artística e demais licenciaturas.

No final do ano de 2010, foi publicada a portaria 260 em 30 de dezembro de 2010, que aprova as "Normas Gerais do Programa Institucional de Bolsa de Iniciação à Docência PIBID". Dentre outros esclarecimentos este documento apresenta os objetivos do PIBID (Item 2.1.1, p.2-3): incentivar a formação de docentes em nível superior para a Educação Básica; 
contribuir para a valorização do magistério; elevar a qualidade da formação inicial de professores nos cursos de licenciatura, promovendo a integração entre a Educação Superior e a Educação Básica; inserir os licenciandos no cotidiano das escolas da rede pública de educação, proporcionando-Ihes oportunidades de criação e participação em experiências metodológicas, tecnológicas e práticas docentes de caráter inovador e interdisciplinar que busquem a superação de problemas identificados no processo de ensino-aprendizagem; incentivar escolas públicas de Educação Básica, mobilizando seus professores como co-formadores dos futuros docentes e tornando-as protagonistas nos processos de formação inicial para o magistério; e, contribuir para a articulação entre teoria e prática necessárias à formação dos docentes, elevando a qualidade das ações acadêmicas nos cursos de licenciatura.

[...] incentivar os jovens a reconhecerem a relevância social da carreira docente; promover a articulação teoria-prática e a integração entre escolas e instituições formadoras; e contribuir para elevar a qualidade dos cursos de formação de educadores e o desempenho das escolas nas avaliações nacionais e, consequentemente, seu IDEB (BRASIL, 2010).

Apenas no ano de 2013, no edital 61 publicado em 02 de agosto de 2013, as instituições privadas puderam também participar do programa. A concessão de bolsas a alunos e professores de universidades, além dos professores da rede pública que integram o projeto, se torna um diferencial do programa.

\section{PIBID/Filosofia Mackenzie/CAPES}

No que se refere ao Projeto Institucional da Universidade Presbiteriana Mackenzie, tem como tema central "A Apreensão do conhecimento por meio da interdisciplinaridade: desafios para a formação docente no século XXI", que norteia a execução de cada subprojeto. Atualmente, são seis licenciaturas participantes mais a do curso de filosofia. Neste sentido, a identidade do professor enquanto educador é totalmente respaldada na esfera acadêmica, pois sente-se a "necessidade de uma formação sólida que ofereça o suporte fundamental para que o educando esteja plenamente consciente de suas atribuições como futuro docente capaz de rever suas fundamentações teóricas conceituais, adequando-as às exigências do cotidiano escolar em que estiver inserido" (CILENTO, 2017, p.3).

A proposta do subprojeto do curso de Filosofia dedica-se à:

A proposta consiste no desenvolvimento de atividades que estimulem
o estudo e instiguem à reflexão filosófica sobre o mundo em que
vivemos, contemplando as relações entre as dimensões do humano
e as diversas áreas da filosofia que se dedicam a fundamentar o
pensamento sobre elas. Nesse sentido, pretende-se sensibilizar
o aluno tanto para a relevância do estudo de filosofia quanto para
a necessidade de uma sistematicidade na análise e na construção 
de um arcabouço conceitual específico da área, considerando o contexto social e cultural no qual os futuros profissionais atuarão, reconhecendo as dificuldades e desafios da prática pedagógica no ensino de Filosofia. No intuito de instrumentalizar a discussão e aprofundar as questões levantadas na sensibilização, serão propostas atividades que planejem e desenvolvam as habilidades de argumentação e raciocínio, tais como debates, exercícios e trabalhos escritos, socializados e discutidos a partir da pertinência argumentativa na produção dos textos. Elaboração de textos finais de cunho acadêmico. Considerando os objetivos, as atividades propostas pretendem desenvolver, inicialmente, uma problematização a respeito das questões éticas no mundo contemporâneo por meio da sensibilização estética. Nesse sentido, serão organizadas jornadas de sensibilização através de manifestações artísticas como cinema, música, teatro, etc., apresentando e produzindo diversas obras concretas e propondo debates sobre o sentido filosófico, ético e estético, analisando seus possíveis significados como manifestações da cultura e visando a compreensão das questões humanas e suas implicações para a construção de valores. (EDITALIPIBIDI2014).

Desde sua implantação - segundo semestre de 2013, várias ações visando a efetivação destes objetivos têm sido tomadas. Se, por um lado, não renunciamos, em momento algum, a apropriação da língua materna - tanto na leitura quanto na escrita dentro da academia, tornando-nos cada vez mais aptos a ler textos filosóficos significativamente - objetivo do Parâmetro Curricular Nacional de filosofia (PCN), bem como auxiliando os professores supervisores no que concerne à esfera do alunado no ensino médio, o pibidlfilosofia têm proporcionado, ao longo de sua trajetória, a potencialização metodológica para o processo ensino-aprendizagem, como prevê o documento:

Ler, de modo filosófico, textos de diferentes estruturas e registros. Uma vez que toda vida humana - no que tem de especificamente humano - está constituída no medium do trabalho e no da comunicação linguística, acredita-se que a capacidade de "compreender os elementos cognitivos, afetivos, sociais e culturais que constituem a identidade própria e a dos outros" (Parecer n 15/98, Resolução $n^{\circ}$ $3 / 98$ ) só pode ser produtivamente efetivada a partir do desenvolvimento de uma competência comunicativo-linguística. Por sua vez, essa competência supõe a capacidade de decodificação dos significados pelos quais construímos a vida em comum e, ao recodificá-los, ressignificá-los, construir uma vida própria, que se constitui simbolicamente numa identidade própria (a qual, por sua vez, está sempre referida à dos outros). A essa capacidade de decodificação/recodificação poder-se-ia designar, genericamente, como leitura. Uma vez que todo aluno, na própria medida do seu ser social-simbólico, já possui uma competência de leitura previamente construída, uma prática de ensino metódica e sistematicamente orientada e conduzida deve favorecer o desenvolvimento dessa competência de realizar tanto uma leitura significativa - filosófica - de textos filosóficos quanto ler, filosoficamente, textos estruturados a partir das configurações discursivas próprias das diferentes esferas culturais. Além 
Compreendemos que a leitura filosófica de textos de diferentes estruturas e registros, conforme apontado no PCN de filosofia, só pode, efetivamente ocorrer quando há uma aprendizagem significativa, conceito que pretendemos esclarecer em seguida e que nos servirá de fundamentação teórica - não a única possível para essa temática - mas que atende ao escopo deste trabalho e às frentes e objetivos do subprojeto PIBIDIFilosofia, o que não significa que outras referências não pudessem ser utilizadas com o mesmo teor de importância.

\section{Aprendizagem significativa}

O conceito de aprendizagem significativa pode assumir diferentes significados a partir de qual perspectiva teórica o mesmo for analisado. Faremos adiante, uma breve síntese acerca das considerações de Ausubel, Rogers e Coll, objetivando conceber definições claras e distintas quanto ao tema em questão.

\section{A Perspectiva Ausubeliana}

O psiquiatra norte-americano David Ausubel, foi um expoente no que diz respeito à estudos relacionados à psicologia educacional. Professor Emérito na Universidade de Columbia (NY), dedicou-se arduamente em formular uma teoria de aprendizagem, além de analisar as suas implicações no processo de ensino e aprendizagem em sala de aula.

Ausubel define a aprendizagem significativa como a ampliação da estrutura cognitiva através da implementação de novas ideias a ela. É o processo em que uma nova informação vai se relacionar com um aspecto relevante na estrutura cognitiva do conhecimento do indivíduo.

Quando determinado conteúdo a ser aprendido, não consegue ligar-se a algo já conhecido, ocorrerá o que o psiquiatra classificará como "aprendizagem mecânica". Em outras palavras, ela ocorre quando novas informações aprendidas não interagem com conceitos presentes na estrutura cognitiva do indivíduo. Assim, toda informação absorvida é armazenada de maneira arbitrária, não há incorporação da informação pelo educando, não permitindo que o processo de aprendizagem seja flexível e longínquo.

Para que a interação entre a estrutura cognitiva e o novo conhecimento adquirido ocorra, é necessário que haja o que Ausubel chamará de subsunçor. Subsunçor é um conceito, uma ideia, uma proposição já existente na estrutura do aprendiz, que serve como "ponto de ancoragem" para uma informação, permitindo ao sujeito dar the um novo significado: "o fator singular que influencia na aprendizagem é aquilo que o aprendiz já conhece. Descubra o que ele sabe e se baseie nisso os seus ensinamentos." (AUSUBEL, 1968, p. 78).

Novas ideias e interações são aprendidas e repetidas na medida em que os conceitos relevantese inclusivos funcionem como pontos deancoragem. Nãoobstante, na ausência de conceitos subsunçores, como pode ocorrer a aprendizagem significativa? Como surgem os subsunçores?

Neste caso, a aprendizagem mecânica se torna necessária, até que o indivíduo 
adquira novas informações em uma área do conhecimento completamente nova para ele. A aprendizagem mecânica ocorre até que os elementos para a formação do conhecimento passem a existir na estrutura e possam assim se transformar em subsunçores. Contrastando com a aprendizagem significativa, Ausubel define aprendizagem mecânica (ou automática) como sendo a aprendizagem de novas informações com pouca ou nenhuma interação com conceitos relevantes existentes na estrutura cognitiva. Nesse caso, a nova informação é armazenada de maneira arbitrária. Não há interação entre a nova informação e aquela já armazenada. $O$ conhecimento assim adquirido fica arbitrariamente distribuído na estrutura cognitiva, sem ligar-se a conceitos subsunçores específicos. A aprendizagem de pares de sílabas sem sentido, é um exemplo típico de aprendizagem mecânica, porém a simples memorização de fórmulas, leis e conceitos, em Física, pode também ser tomada como exemplo, embora se possa argumentar que algum tipo de associação ocorrerá nesse caso. Na verdade, Ausubel não estabelece a distinção entre aprendizagem significativa e aprendizagem mecânica como sendo uma dicotomia e sim como um contínuo (MOREIRA, 1999, p. 154).

Outra ferramenta importante na formação de subsunçores são os organizadores prévios, que podemos definir como materiais introdutórios apresentados antes do material a ser aprendido em si. (MOREIRA, 1999, p. 155). A principal função desses organizadores é auxiliar na ligação entre o que o aprendiz já sabe e o que deve saber. Fazemos menção aqui a um 'ancoradouro provisório' para uma nova informação. É uma ferramenta não permanente, que culmina no desenvolvimento de conceitos subsunçores que facilitam a aprendizagem seguinte.

Doravante, de acordo com a perspectiva ausubeliana, para que a aprendizagem significativa ocorra, são necessárias duas condições. A primeira está inteiramente ligada ao indivíduo, já que segundo Ausubel, o aprendiz precisa ter uma disposição para de fato, aprender. Caso o educando apenas almeje memorizar o conteúdo de modo arbitrário, o seu processo de aprendizagem será mecânico. A segunda condição é que o conteúdo a ser aprendido seja potencialmente significativo, relacionável à estrutura cognitiva do aprendiz, de modo não arbitrário e não literal. Esta condição não está associada apenas ao fato de que o material de ensino seja em sua essência não arbitrário, todavia está diretamente ligada ao aprendiz, já que o mesmo deve dispor dos subsunçores necessários para o êxito no processo de ensino e ancoragem do conhecimento. Logo, pensar apenas em conteúdos logicamente significativos, não é suficiente. É preciso sondar os interesses e experiências dos alunos, para que os conteúdos sejam psicologicamente significativos (SANTOS, 2013, p. 54-55).

As considerações de Ausubel partem do pressuposto que os indivíduos detêm uma organização cognitiva interna baseada em conhecimentos de caráter conceitual. As relações que esses conhecimentos estabelecem, determinam a complexidade dos conceitos a serem aprendidos. Estas relações, por sua vez, são organizadas hierarquicamente, de modo que, a estrutura cognitiva, é compreendida, sobretudo, como uma rede de conceitos organizados de modo hierárquico de acordo com o grau de abstração e generalização (SANTOS, 2013, p.55).

Podemos, portanto, destacar que a aprendizagem se torna significativa a partir do 
momento em que a ampliação da estrutura cognitiva quando para além da memorização, há a apropriação daquele conteúdo por meio dos subsunçores; quando para além da imposição há disposição. Estes, são elementos importantes a serem retomados na última parte do nosso trabalho, pois o Projeto de Iniciação à Docência - PIBID cria as condições de possibilidade este tipo de aprendizagem por meio de sua metodologia inovadora que conta com a participação ativa de todos os sujeitos envolvidos. Além disso, permite o que Ausubel chama de 'ponto de ancoragem' - ou seja, por vezes, não só partem daquilo que já sabem como também ampliam seu 'arsenal teórico': e tal processo se dá em várias esferas. A primeira, na Universidade, a cada aula. A segunda, na elaboração conjunta do professor-supervisor e licenciandos da sequência didática a ser ministrada, pois isso requer pesquisas complementares para que as intervenções planejadas surtam o efeito desejado.

Aqui ainda podemos mencionar que o PIBID consegue de modo efetivo, permitir aos licenciandos o conhecimento da realidade do cotidiano escolar - diferentemente do estágio no modelo tradicional que apenas permite a observação do licenciando às aulas. A terceira esfera concerne à aprendizagem dos alunos do ensino médio da escola parceira, pois o ensino de filosofia lhes possibilita uma "lente da qual ele pode olhar o mundo" (SEVERINO, 2010) ou nas palavras do prof. Celso Favaretto, "repertório de topói" à medida que exercitam suas habilidades de leitura e de interpretação de texto.

\section{A Visão de Rogers}

A concepção de aprendizagem significativa foi objeto de análise em muitos estudos do psicólogo americano Carl Rogers. Adepto da corrente da psicologia denominada humanista, se tornou referência ao aplicar à educação princípios da psicologia clínica.

Enquanto o behaviorismo caminha por um viés determinista e reforça o comportamento estímulo-resposta, a visão humanista surge em contrariedade às ideias comportamentalistas. A abordagem humanista - no campo da educação - concebe que o ato de aprender é fundamentalmente individual e atribui a experiência subjetiva uma grande importância, pois o educando só assimila aquilo que lhe é entendido como importante e/ou está associado com a sua realidade.

Por aprendizagem significativa, entendo uma aprendizagem que é mais do que uma acumulação de fatos. É uma aprendizagem que provoca uma modificação, quer seja no comportamento do indivíduo, na orientação futura que escolhe ou nas suas atitudes e personalidade. É uma aprendizagem penetrante, que não se limita a um aumento de conhecimentos, mas que penetra profundamente todas as parcelas da sua existência. (ROGERS, 1999, p.322). 
Rogers enxerga o ser humano como fundamentalmente bom e curioso, não obstante, acredita que esta precisa deajuda para evoluir. Afigura do professorem um processo deensino-aprendizagem significativo deveserde intermediador. O docente devese basearnas condições essenciais de facilitador, tal qual aceitação condicional, empatia, congruência e autenticidade. Contudo, é prudente que analisemos de modo sintético, as características dessas condições facilitadoras.

A aceitação condicional valoriza a individualidade do aprendiz - sentimentos e opiniões. Essa atitude pressupõe que o tutor deve aceitar os questionamentos do discente, que certamente surgirão no processo de aprendizagem. O ambiente escolar deve ser acima de tudo compreensivo e encorajador, objetivando o progresso do educando.

Relacionada à colaboração para a construção de um ambiente favorável para o aprendizado, o objetivo maior é o da empatia, a valorização dentro do ambiente de ensino, a alteridade, posto que se o estudante percebe que o seu modo de ser é compreendido, há grande possibilidade que uma aprendizagem sólida seja construída.

Um fator importante a ser acrescentado nesta perspectiva é a congruência. Este conceito concerne à relação direta de determinada coisa ou situação, com o fim que é destinado, ou seja, a manifestação de como se é e como se sente. Assim como o professor, o aprendiz deve ser fiel aos seus sentimentos e sensações, almejando construir uma interação entre docente e aprendiz uma relação honesta e sincera.

Apesar da real complexidade desse conceito de congru-
ência, creio que todos a reconhecemos de um modo intui-
tivo e natural nos indivíduos com quem tratamos. Reco-
nhecemos num indivíduo que ele não só pretende dizer
exatamente aquilo que diz, mas seus sentimentos mais profundos
se revelam naquilo que está expressando. (ROGERS, 1999, p.325).

A autenticidade, decorrente da proposta de congruência e empatia, refere-se ao ser verdadeiro. O educador deve promover uma relação verdadeira, sem almejar deturpar a situação por conveniência. As colocações, por exemplo, acerca de aprovações ou reprovações, devem ser expressas pelo aluno e professor de maneira mais transparente possível, sem que as atitudes sejam entendidas como agressoras.

A existência de um ambiente escolar motivador, ausente de preconceitos e julgamentos, junto a promoção do processo de ensino-aprendizagem que respeite os limites da razão e sentimentos do aprendiz, é o que para Rogers representa a possibilidade de uma aprendizagem significativa.

A visão de Rogers para o que denomina de aprendizagem significativa também se torna importante para a confecção deste trabalho quando aponta para três elementos: o primeiro é que a aprendizagem é individual e é derivada de uma experiência subjetiva, onde são levados em conta os sentimentos e as opiniões dos educandos. Ora, neste aspecto, o PIBID contempla a valorização de cada indivíduo envolvido com o projeto. $O$ aluno do ensino médio, com o espaço de criação por meio da sensibilização estética - objeto do subprojeto do PIBIDIMackenzie. Após se apropriarem do referencial teórico, os alunos são 
convidados a participarem das intervenções propostas - e várias delas são advindas dos licenciandos que, por sua vez, também são valorizados. Essa relação se dá pela abertura e sinceridade que os alunos, licenciandos e professores do ensino médio e da universidade se dispõem a ouvirem as ideias levantadas, em profunda congruência, em todas as esferas mencionadas acima. Com as produções, os alunos se sentem motivados e valorizados, os licenciandos testam suas habilidades e se sentem orgulhosos quando percebem que suas ideias também puderam ser expressas por meio das produções dos alunos. Por seu turno, os professores também em busca de referenciais teóricos adequados para cada intervenção e sugestões percebem a modificação no comportamento de seus respectivos alunos.

\section{A Visão de Coll}

Diretor do Departamento de Psicologia Evolutiva e professor da Faculdade Psicologia da Universidade de Barcelona, César Coll Salvador é referência em educação na contemporaneidade. Coordenador da "Renovação Pedagógica" - reforma do ensino que ocorreu em 1990 na Espanha, teve seu modelo pedagógico apontado como referência e inspirou mudanças em diversos países, incluindo o Brasil. O professor também atuou como consultor do Ministério da Educação do Brasil (MEC) e colaborou efetivamente para a elaboração dos nossos Parâmetros Curriculares Nacionais. Coll (SANTOS, 2013, p.59) associou a disposição para aprendizagem proposto por Ausubel, como um dos enfoques de aprendizagem dados pelos próprios alunos, ao serem indagados sobre a forma como realizavam a tarefa de estudar: "O enfoque profundo".

O objetivo deste enfoque é promover nos alunos a compreensão do que estudam, quais as possíveis motivações que os aproximam ao conteúdo que estudam os seus conhecimentos prévios, suas experiências pessoais ou outros assuntos, a avaliar o que está sendo realizado e a preservar até conseguir um grau aceitável de compreensão. O "enfoque profundo da aprendizagem", apresenta-se de modo inteiramente oposto ao "enfoque superficial da aprendizagem", pois nesta os anseios do aluno são limitados ao cumprimento dos requisitos das tarefas, posicionando a compreensão real do conteúdo, em um segundo plano.

Para SANTOS (2013) aprendizagem profunda (aprendizagem significativa), a intenção de compreensão e a forte interação com o conteúdo são protagonistas. A relação de novos conceitos com conceitos subjacentes, junto a experiência cotidiana, ocorre de modo efetivo. Existe um exame da lógica dos argumentos. Já na aprendizagem superficial, não há espaço para reflexão sobre os propósitos do aprendizado. A memorização de informações necessárias para provas, o cumprimento de requisitos da tarefa, impossibilitam pensar sobre os fundamentos.

É salutar salientar que esses enfoques se aplicam ao modo de abordagem da tarefa, e não ao aluno em si. O aluno pode transformar o seu enfoque de uma tarefa para outra, de uma disciplina para outra ou de um professor para outro.

Para Coll, o educando pode apresentar maior ou menor disposição para aprendizagens significativas a partir de dois fatores: a natureza do aluno e a própria situação de ensino 
que se estabelece. Interessar-se por determinada "coisa", implica entender que essa "coisa" sanará alguma necessidade. Quando o aluno não toma ciência do propósito de uma tarefa, quando não compreende de que forma realizar determinada tarefa contribuirá para si mesmo, dificilmente realizará um estudo profundo sobre a questão (SANTOS, 2013, p. 60-61).

Nas escolas onde os métodos de ensino fomentam a dependência, 0 excesso de trabalho e falta de tempo são frequentes, a aprendizagem superficial tende a prevalecer. Apenas quando os alunos são encorajados ao total envolvimento nas atividades de modo racional, os mesmos tenderão à autonomia.

A terceira vertente da aprendizagem significativa - a de Coll nos coloca o desafio do protagonismo estudantil - conceito tão discutido ultimamente. Ora, o que se espera é que os estudantes consigam refletir sobre os fundamentos, para além de uma aprendizagem mecânica, de pura repetição e encontrem sentido nas atividades que estão sendo desenvolvidas. Coll também nos alerta para um segundo ponto que é o deslocamento da passividade para o da atividade. Nesse sentido, o Projeto de Iniciação à Docência provoca o encorajamento dos estudantes, pois suas reflexões acerca dos fundamentos - objeto primeiro da filosofia, que é corroborado pelas outras disciplinas no caso do ensino médio, possibilita um avanço em sua autonomia.

Processo este que começa a ser desencadeado no ensino médio e perdura por toda a vida. Exatamente porque os educandos não são apenas um repositório de conteúdo, ou nos valendo da expressão de Paulo Freire - "educação bancária" (FREIRE,1987, p.33), no PIBID, os educandos são levados a buscarem a autonomia, realizando uma síntese, seja no âmbito meramente intelectual, seja no da possibilidade de expressarem-se por meio das sensibilizações estéticas proporcionadas durante o projeto.

Por fim, dada à limitação de espaço que temos para a apresentação deste trabalho, reforçamos que o conceito de aprendizagem significativa proposto pelos três autores aqui estudados serve de subsídio teórico para análise e para o relato de experiência que faremos a seguir. Salientamos que outros autores serviriam e corroborariam para este momento, entretanto, quisemos aprofundar nossas considerações por meio deste conceito.

\section{O PIBID e a aprendizagem significativa}

\section{Ações Previstas}

Selecionamos algumas das ações previstas para conhecimento, mas também como suporte para esta última parte. Para tanto, será necessário nos voltarmos ao subprojeto de Filosofia. Segundo o edital de 2014, esclarece que:

Os alunos de Licenciatura em Filosofia que estarão envolvidos neste projeto desenvolverão ações que efetivamente articulem a sua formação acadêmica a práxis da docência na Educação Básica, visando o aprimoramento de suas habilidades assim como a compreensão do processo educacional, ou seja, o conhecimento da prática escolar pelos graduandos. Assim sendo, estabelecemos tais ações: 
a) permitir o contato com o cotidiano escolar por meio de observações e participação nas relações de interação entre professor, aluno e profissionais da educação. b) travar conhecimento com o projeto pedagógico da escola, da proposta de ensino de Filosofia, levantamento do conteúdo ministrado na área de Filosofia e das inquietações que surgem na aula de Filosofia.

c) planejar e organizar as atividades de sensibilização: 1. discutir e detalhar, em conjunto com os docentes da Educação Básica envolvidos no projeto, as atividades a serem desenvolvidas em relação à sensibilização estética e às obras selecionadas. 2. Preparação destas atividades envolvendo textos, exercícios e outras que evidenciem para os alunos a construção de sentidos pertinentes às temáticas levantadas. d) Realizar e registrar os dados parciais acerca da avaliação diagnóstica dos alunos, quanto às suas dificuldades e interesses. e) Analisar e avaliar os resultados parciais e replanejamento das ações docentes, caso necessário. g) Promover a produção, com os alunos da Educação Básica, do material resultante desta sensibilização: cinema, teatro e música, assim como a de obras concretas dos próprios alunos. h) Promover a produção, com os alunos da Educação Básica, do material resultante desta sensibilização: cinema, teatro e música, assim como a de obras concretas dos próprios alunos. i) Planejar e organizar os trabalhos escritos, socialização e discussão, a partir das temáticas apresentadas. j) Avaliação dos resultados finais e diagnóstico das dificuldades. k) Participação em congressos e eventos relacionados ao PIBID e às licenciaturas em geral. I) Participação dos licenciandos e do professor coordenador no GT de Ensino de Filosofia da ANPOF com apresentação de trabalhos, bem como nos Encontros Nacionais do PIBID Filosofia, conforme Carta de Vitória durante o vigor do projeto. Cabe também dentre as ações previstas, a vivência do cotidiano escolar pelos graduandos, como a participação em reuniões de pais e mestres, em conselhos de classe, e na colaboração de construção de projetos comuns à escola da Educação Básica. Também está contemplado o envolvimento do aluno em situações de conflito e suas possíveis resoluções, tendo em vista a participação dos futuros professores em todas as situações relacionadas ao processo ensino-aprendizagem. (EDITALIPIBIDIFILOSOFIA, 2014).

Para este momento, foi preciso selecionar as atividades realizadas nas escolas públicas parceiras. Sentimo-nos também no direito de, como ex-pibidiano e agora docente, relatar nossa experiência na docência. A fim de ilustrar este processo, tomamos como referência os relatórios anuais do PIBID/FILOSOFIA/MACKENZIE/CAPES como base para esta seleção. Portanto, dividimos nossa exposição em três partes distintas, partindo das Produções dos Licenciandos, posteriormente apresentando as Produções dos Alunos do Ensino Médio e por fim, o Relato de Experiência de um ex-pibidiano que participou do programa de fevereiro de 2015 a dezembro de 2016, e este período em que atuamos será nosso recorte. 


\section{Alunos do Ensino Médio}

Os alunos do ensino médio das escolas que participam do PIBID, representam uma parcela fundamental para a efetivação do programa. É através deles e de suas respectivas salas de aulas, que os bolsistas podem enxergar os reais desafios da docência na contemporaneidade. Os bolsistas, frente à proposta do projeto e almejando promover a aprendizagem significativa dos conteúdos propostos, trabalham na produção de material e aulas que possam de fato fomentar um tipo de aprendizagem que não seja mecânica. Ora, estas ações corroboram o que prediz o tópico G): "Promover a produção, com os alunos da Educação Básica, do material resultante desta sensibilização: cinema, teatro e música, assim como a de obras concretas dos próprios alunos."

A maioria das intervenções do PIBIDIFilosofia são realizadas a partir do planejamento conjunto entre professor-supervisor e os licenciandos, de modo que nossa primeira preocupação reside na habilidade de ler textos filosóficos - objetivo do PCN de Filosofia e por meio da metodologia diferenciada do Programa, promover a aprendizagem significativa.

A melhor maneira que encontramos a de explicitar por exemplos - conforme nos salienta Santana (1979), dada as múltiplas intervenções realizadas no decorrer deste período.

Selecionamos duas delas: A primeira, ocorrida no segundo semestre de 2015, desenvolvemos o projeto denominado A Arte e a Loucura: um diálogo com a cidade, consistindo em representações artísticas feitas em sala de aula pelos alunos, com base nos temas apresentados ao decorrer das aulas ministradas pelo professor e os integrantes do PIBID.

A construção do projeto teve como principal foco o caráter interdisciplinar na maneira de pensar o tema proposto aos alunos, de maneira que fora possível relacionar obras de literatura brasileira, junto a temas tratados na história da filosofia. A proposta do projeto elaborado pelos bolsistas para o $2^{\circ}$ semestre de 2015 , buscou trabalhar com os alunos as habilidades e competências referentes à leitura, escrita e interpretação textual. Partimos da explicação do conceito de Justa Medida da Ética a Nicômaco de Aristóteles e partir dele trabalhamos a ideia do homem como animal político e a relação da cidade/polis com a felicidade, onde os alunos deveriam produzir um painel de fotos cujo conteúdo ilustrasse o conceito trabalhado e como a desmedida que contraposta a justa medida poderia figurar como loucura, quando um cidadão que se encontra em desmedida assim atua frente à cidade/polis.

Trabalhamos de modo transversal a história da loucura em Foucault para pensar o louco na sociedade como aquele que desafia a ordem e perturba a harmonia social, para tal nos utilizamos de artigos de mídias digitais e impressas que abordavam as questões da depressão e da loucura como um fenômeno próprio da vida na metrópole, convergindo deste modo os dois pensadores trabalhados. Efetuamos a leitura estrutural de um trecho selecionado da obra de Aristóteles referente ao conceito apresentado, seguidos da leitura da narrativa: O alienista de Machado de Assis que figurou como exemplo deste conceito aristotélico e sua relação com a abordagem que propomos de Foucault. A parte estética se deu na produção de painéis de fotos tiradas pelos alunos e na produção de uma ilustração/ xilogravura que representava a desmedida/loucura por eles observadas no cotidiano de nossa sociedade. Cenas que poderiam nos levar a loucura ou que poderiam ser consideradas 
como tal, onde a partir delas os alunos puderam refletir sobre o conceito de loucura e de normalidade em um diálogo com a cidade. Nosso trabalho foi efetuado em conjunto com professores de outras disciplinas em especial de português e artes que tomaram o tema proposto em suas aulas e nos permitiram assim um trabalho interdisciplinar e dinâmico.

Em sala, durante as aulas de filosofia, foram trabalhados pensadores como Aristóteles e Foucault. Com o primeiro pensador, foi trabalhada a temática sobre a vida do homem em sociedade, como chamado "animal político" e a "justa medida" necessária para uma vida ética e feliz, já com o segundo pensador, foi trabalhado o conceito de "loucura", demonstrando a política de exclusão e sua própria definição como algo que seja fora de um padrão socialmente estabelecido.

As manifestações feitas pelos alunos foram divididas em duas representações: Painéis e Xilogravuras. A primeira tinha como foco apresentar e (ou) representar sob a ótica dos alunos uma sociedade desmedida, fora de toda harmonia e justa medida trabalhada nas aulas sobre Aristóteles, através de imagens e pequenas mensagens. A segunda manifestação artística, trabalhada com o pensamento de "loucura" em Foucault, representada em xilogravuras criadas pelos alunos, empenhava a proposta de apresentar situações que causassem ou demonstrassem sinais de loucura no homem atual, em toda sociedade contemporânea.

Figura 1 - Projeto: a arte e a loucura: um diálogo com a cidade. Professor Odair e bolsistas do PIBID

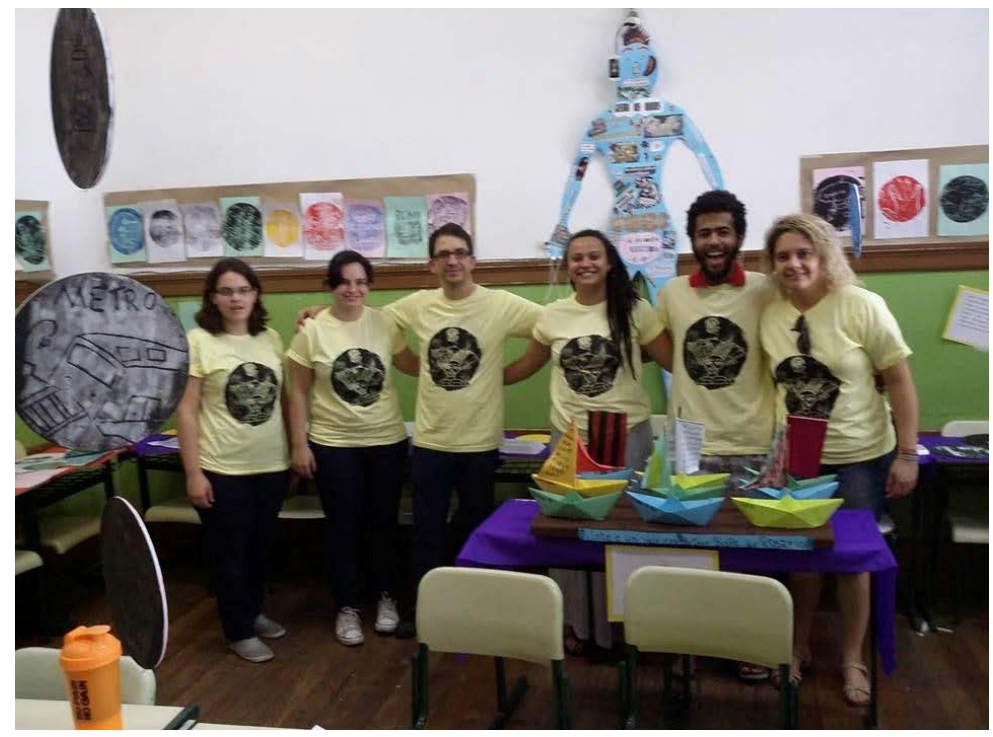

Figura 2 - Projeto: a arte e a loucura. virada cultural. Produção de xilogravuras

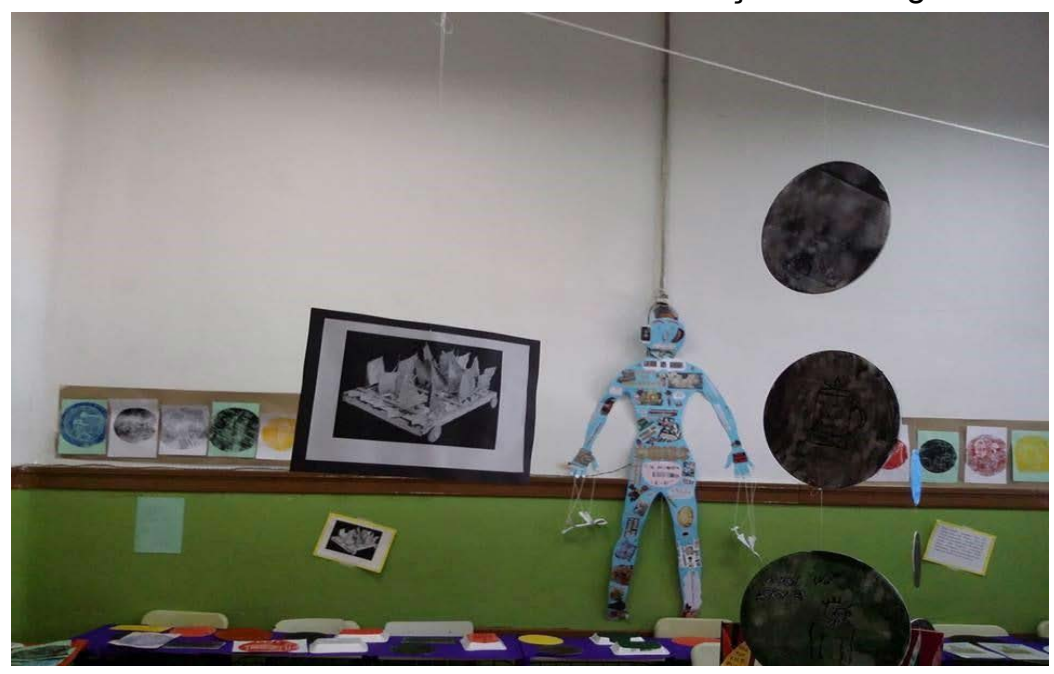


Figura 3 - Produção de painéis com citações, fotos, depoimentos

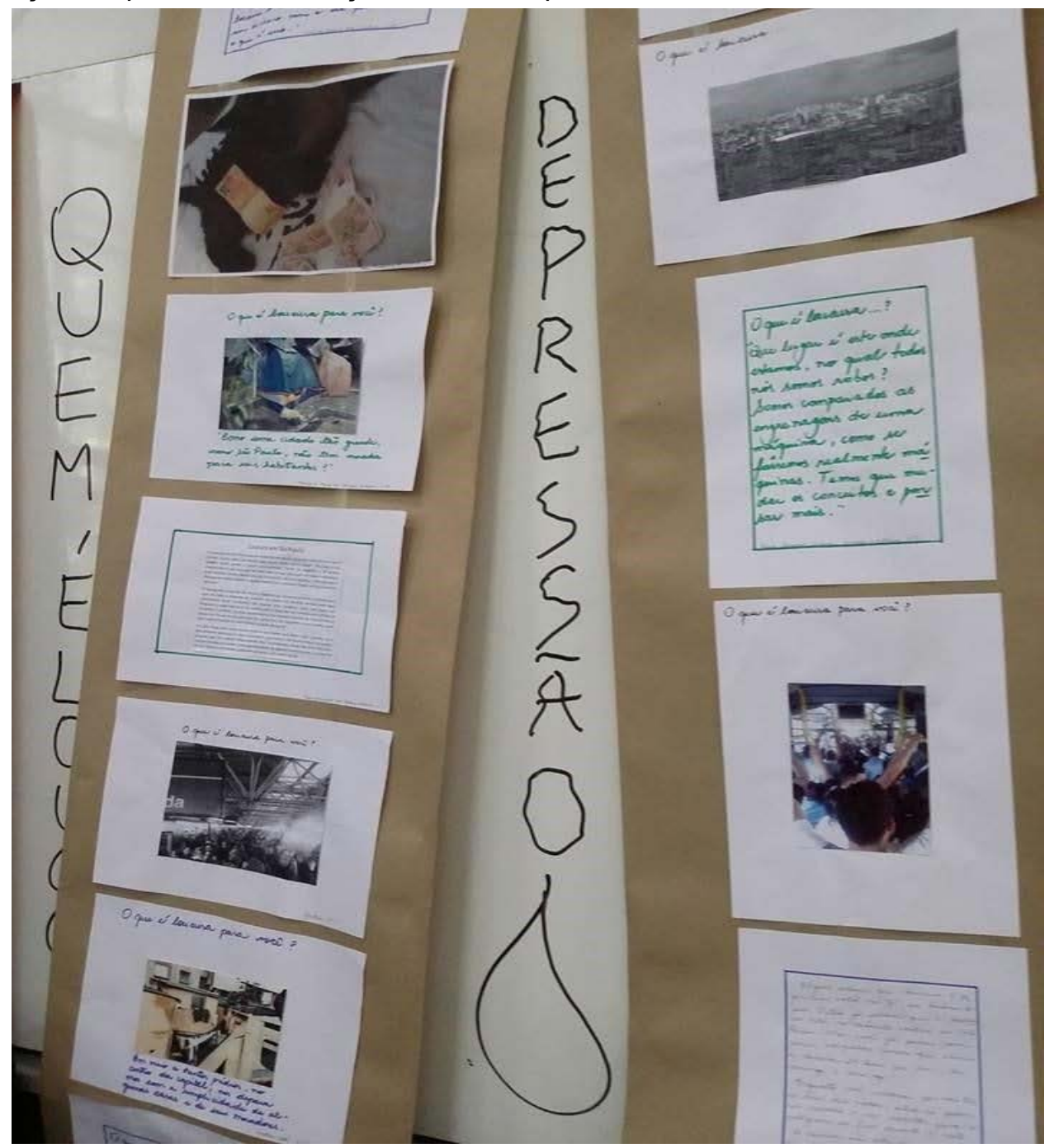

Figura 4 - Produção de xilogravuras

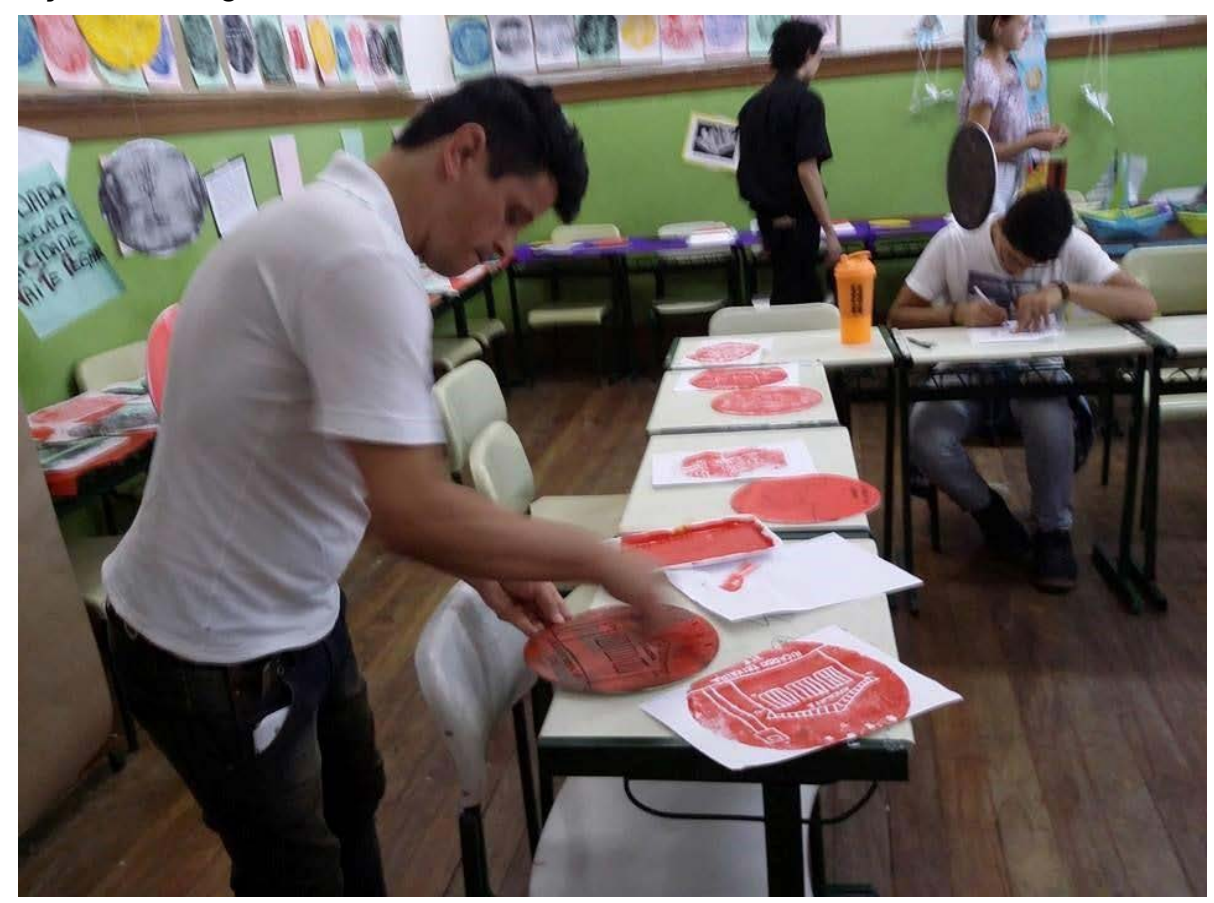


A segunda foi realizada no primeiro semestre de 2015 . O projeto foi calcado na "construção do imaginário popular".

Figura 5 - Aula expositiva sobre mitologia grega

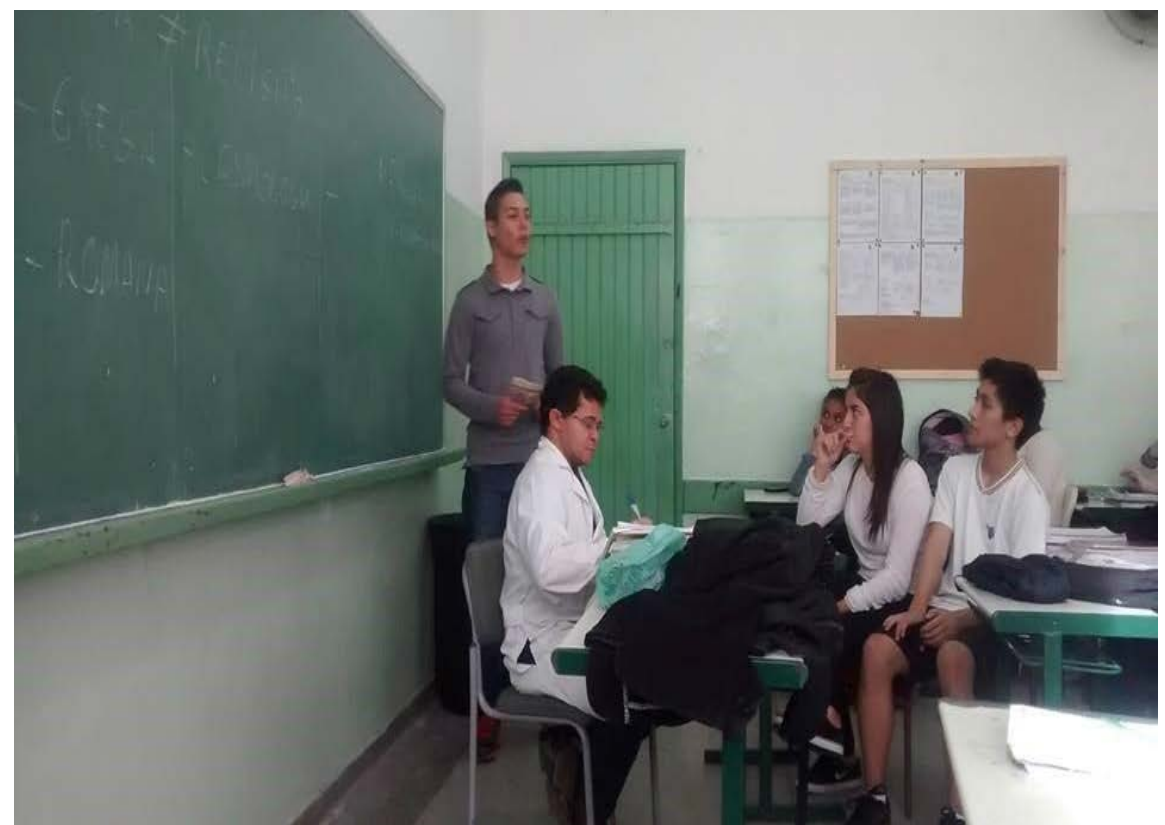

Figura 6 - Parte da exposição artístico-cultural sobre "os heróis contemporâneos"

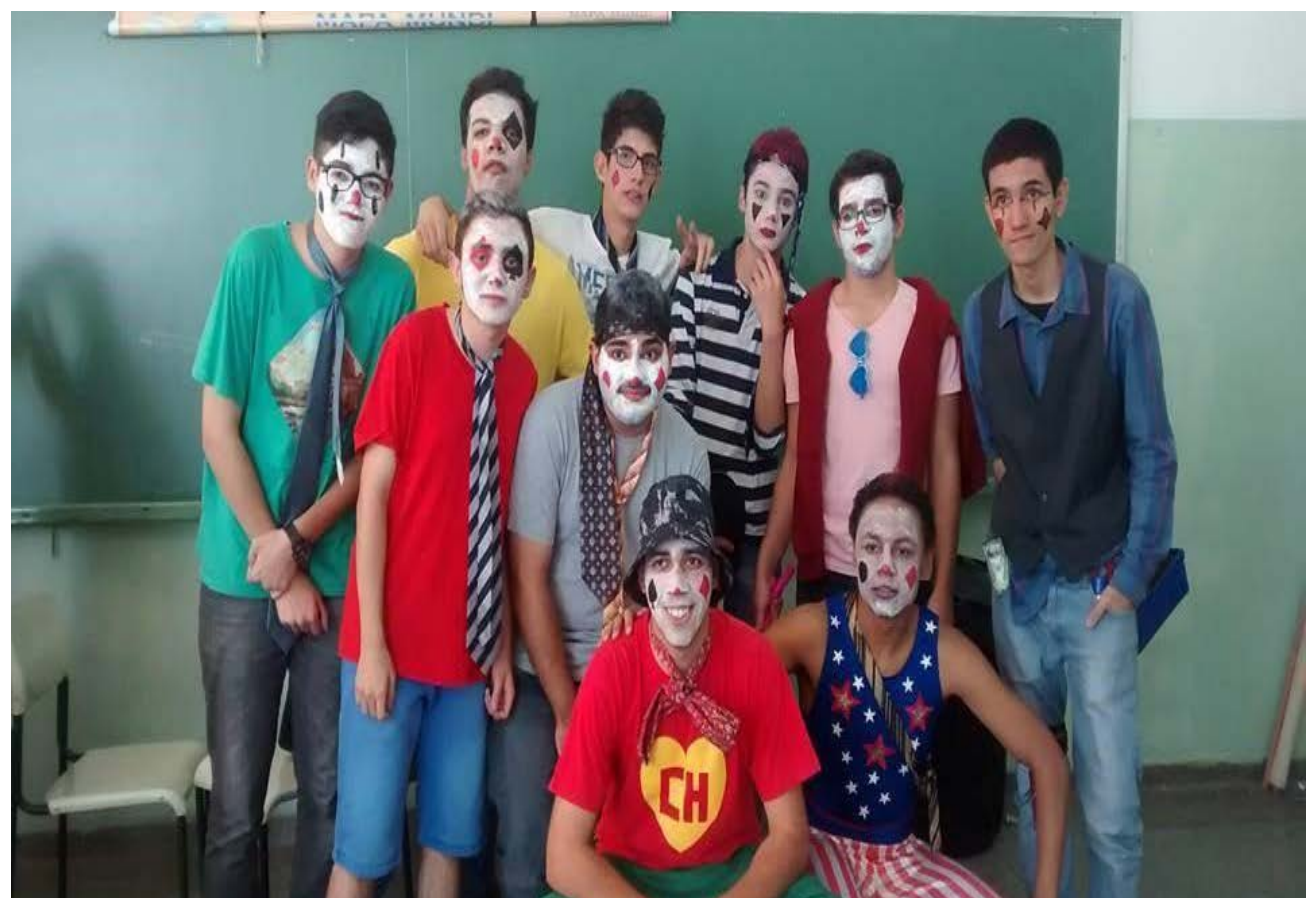




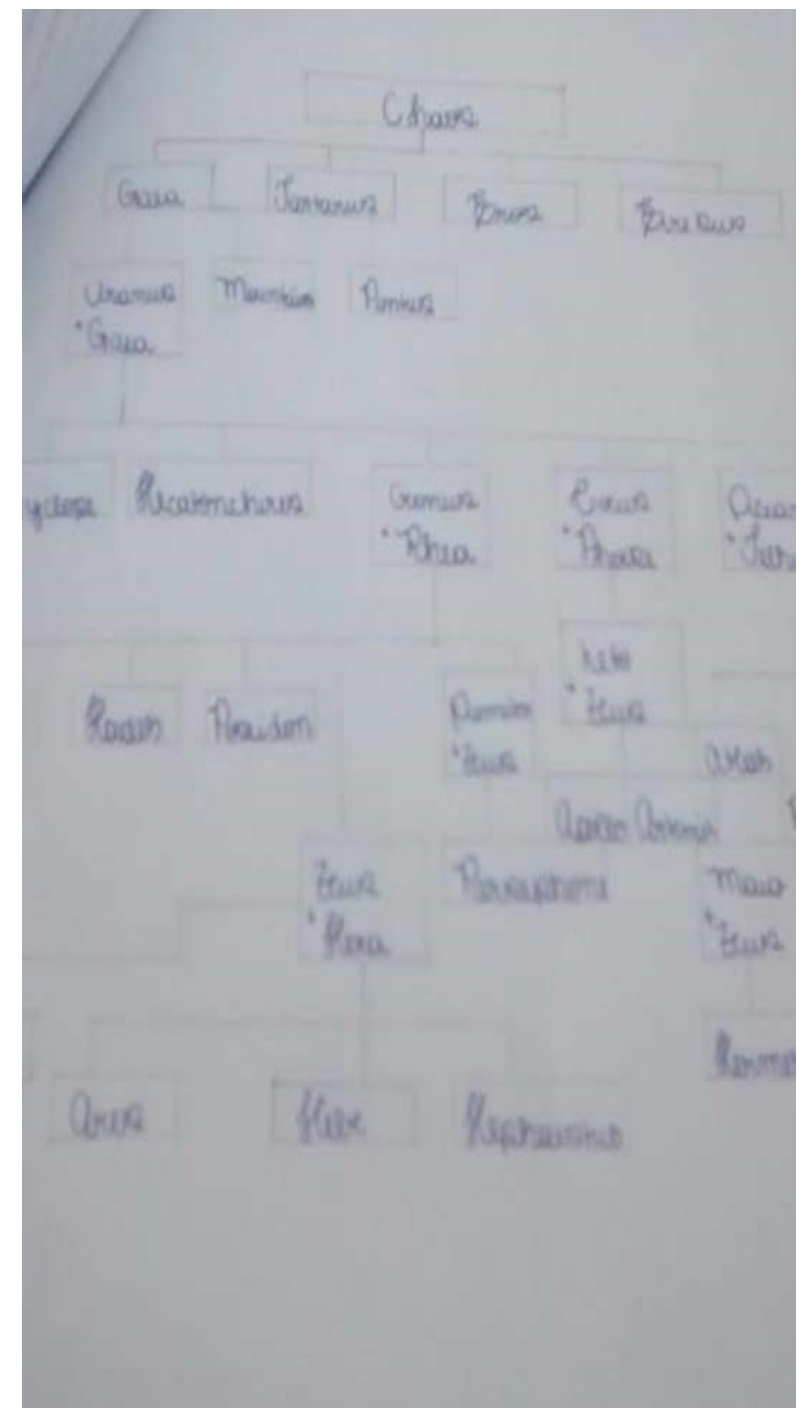

Primeiramente, durante quatro semanas, os bolsistas e professor supervisor discutiram, pesquisaram e elaboraram uma sequência didática para a execução do projeto. A aplicação consiste em três etapas: conceito, pesquisa e execução.

1. Conceito - Os alunos aprenderam conceitos básicos de filosofia e estética para começarem desenvolverem o projeto no plano teórico sem maiores dificuldades. 2. Pesquisa - Nesta fase, os alunos realizaram pesquisas relacionadas ao projeto proposto pelo PIBID, a partir do conceito teórico planejado, em diversas fontes: livros, jornais, internet, revistas, etc.

3. Execução - Foi a última parte do planejamento no qual os alunos imbuídos dos conceitos teóricos puderam expressar-se artisticamente na forma de telas, fotos, de filme, peças de teatro, quadrinhos, músicas, obras literárias e ideias do gênero. Após a finalização da aplicação, o projeto foi apresentado na escola, o que explicita a ideia de compartilhamento.

Podemos observar que estas duas ilustrações das intervenções são o coroamento de uma aprendizagem significativa para os alunos do ensino médio à medida que vários dos elementos do conceito são perceptíveis: os subsunçores de Ausubel, a disposição, a consciência do propósito das tarefas a serem 
executadas, o encorajamento dos estudantes e seu consequente protagonismo, conforme nos salienta Coll; a experiência subjetiva e a congruência que só pode existir em uma verdadeira parceria entre professor, licenciandos e alunos, conforme nos aponta Rogers.

Neste sentido, não foi possível dissociar a importância do papel docente: o de desafiar os alunos. Por isso, o planejamento e a organização das atividades, conforme salienta $\mathrm{O}$ item $\mathrm{C}$ das ações previstas no PIBIDIFilosofia se tornam imprescindíveis. Aqui há a verdadeira articulação entre a academia e a práxis docente e um esclarecimento ímpar para a compreensão do processo educacional.

Com o planejamento destas intervenções, construirmos nossa própria forma de "desequilibrar" as redes neurais dos alunos, a fim de provocar a "instabilidade cognitiva". Planejar uma aula significativa implica, buscar formas criativas e estimuladoras de desafiar as estruturas conceituais dos alunos. Essa necessidade nos poupa da tradicional busca de maneiras diferentes de "aprender a matéria". (SANTOS, 2013, p. 66).

\section{Produções dos Licenciados}

A fim de contemplar as outras ações previstas do Programa, tais como a escrita de trabalhos acadêmicos, a participação de congressos e eventos - tópicos I e K, selecionamos algumas das produções acadêmicas no período recortado para este trabalho.

Em 2015, os bolsistas e professor coordenador do projeto, participaram da comissão organizadora do II Encontro Nacional do PIBIDIFilosofia, realizado na UFABC entre os dias 01 e 03 de junho do ano em questão. O trabalho "DESAFIOS DA DOCÊNCIA: Cristalização e plasticidade, limites e potencialidades no ensino de filosofia e a aplicabilidade do PIBID" objetivou compreender o universo da docência como um espaço compósito e os limites e potencialidades do PIBIDI FilosofialMackenzie diante do projeto - o ensino de filosofia por meio da sensibilização estética.

A edição 66 da Revista Pandora (ISSN 2175-3318), teve a sua temática inteiramente voltada ao PIBID. Publicada em agosto de 2015, com o título "Os impactos do PIBID na Universidade: uma experiência de criação de material didático-pedagógico na disciplina Oficina de Práticas Pedagógicas I". Esta edição contou com artigos de bolsistas, que em seus artigos, expuseram as produções efetivadas no decorrer do projeto. As produções publicadas pelos pibidianos, estão todas relacionadas à produção de jogos que serviram de ferramenta para o ensino de filosofia. Alguns bolsistas expuseram em seu artigo o jogo online que produziram cujo a temática é a história da filosofia. Jonatan Teixeira Alves, mostrou em sua publicação a produção do "Dominó de Silogismos", um jogo que tem como objetivo facilitar o ensino de lógica.

No ano de 2016, os alunos participaram do Seminário Interno do curso de Filosofia. Apresentaram a palestra cujo tema foi: PIBID - DESAFIOS E REALIZAÇÕES. O trabalho contou com a apresentação do programa de iniciação à docência para os demais alunos do curso de filosofia e visitantes. Ex-pibidianos e atualmente professores da rede pública e particular, participaram depondo sobre a sua atuação na docência e a contribuição do PIBID na sua formação.

Ainda em 2016, ocorreu a II Mostra do PIBID da Escola Estadual Major Arcy, com o tema "Reconstruindo Paradigmas". Com uma intensa programação que incluía a apresentação 
de todos os projetos de PIBID, realizados naquela escola, O PIBID/MACKENZIE apresentou todas as atividades até aquele momento realizadas com as turmas de ensino médio.

Ora, tais publicações nos remetem novamente ao conceito de aprendizagem significativa e aos objetivos do PCN de filosofia, promovendo uma verdadeira articulação entre a academia e a práxis. Em segundo lugar, retomamos as ideias do protagonismo estudantil - que não se limitou apenas à assimilação dos conteúdos específicos da disciplina, mas pudemos ousar, no sentido de refletirmos a respeito da docência e propusemos a criação de novas as práticas, como a criação de jogos dentro e fora das salas de aula da licenciatura, conforme Revista Pandora 66. Este processo fez florescer em cada um de nós a busca pelo aprimoramento pessoal - a ser desenvolvido no próximo tópico deste trabalho.

\section{Relato de Experiência}

Nada melhor para a explicitação de um conceito do que 'ilustrar como exemplo', conforme nos salienta SANTANA (1979). Portanto, neste momento que se abre pretendo discorrer sobre a minha própria aprendizagem significativa-e, por conseguinte, peço permissão para não falar agora na primeira pessoa do plural, como viemos fazendo até o presente momento deste trabalho, mas colocar as minhas experiências pessoais, como ex-pibidiano e agora professor do ensino médio.

Achamos pertinente inserir este relato pois, conforme aponta o PCN de Filosofia, lemos:

O ensino de filosofia pode contribuir, portanto, para 'plano pessoalbiográfico', uma competência de contextualização a partir de conhecimentos filosóficos pode ser muito importante na compreensão de determinadas vivências, sem falar, é claro, da riqueza que o imenso panorama filosófico tem a oferecer como contribuição na tarefa de construir uma (ou reconhecer-se numa) visão do mundo cujos pressupostos busquem fundamentar-se de modo refletido, crítico. (...) reconhecer suas capacidades, potencialidades e dificuldades; abrir-se para as diferenças discursivas e habilitar-se a aprender com argumentos morais, entre tantas outras coisas. (MEC, 1999, p.58)

Cursando o segundo semestre da graduação, procurei uma escola para que pudesse cumprir o estágio obrigatório requisitado pela Universidade. Cheguei até u uma escola estadual, situada na periferia de Taboão da Serra - SP, foi também a escola que cursei o ensino fundamental e médio.

Ao conversar com o então diretor da unidade escolar sobre todas as questões burocráticas referentes ao estágio, fui surpreendido quando o mesmo me perguntou: "estamos com uma enorme carência de professores eventuais aqui na escola, você não tem interesse de se tornar um professor eventual e fazer parte do nosso corpo docente?" Em um primeiro instante, fiquei assustado e ao mesmo tempo entusiasmado com o convite, prontamente agradeci a oportunidade e prometi que iria pensar sobre o assunto. Inteiramente inseguro com a possibilidade, conversei muito com os meus pais - que também atuam na área da educação - e com alguns professores da universidade. Todos me encorajaram a assumir o 
desafio. Foi então que no dia 5 de setembro de 2013, iniciei minha trajetória como professor.

Os dias como professor eventual foram difíceis. Era um tanto desafiador trabaIhar uma sequência didática com as salas, já que ao entrar em uma turma, dificilmente saberia quando retornaria, pois, o professor eventual só entra em sala quando o professor titular falta, sem contar, que no imaginário popular, uma aula ministrada por um professor eventual, representa algo com mínima possibilidade de atividade. Como promover uma aprendizagem significativa em esporádicos 50 minutos de aula? A solução que encontrei foi a elaboração de um plano de ensino, baseado nos temas transversais contidos nos PCN's (Parâmetros Curriculares Nacionais). Os temas em questão, são todos relacionados à cidadania e felizmente gerou bastante interesse nos alunos. As aulas eram bastante dinâmicas e interativas. Apesar da pouca regularidade das aulas, conseguimos alcançar resultados certamente muito além do esperado, pois falávamos de assuntos que estavam diretamente presentes no cotidiano dos alunos. Em outras palavras, as aulas eram apenas uma teorização da vida real de cada um deles.

Por conseguinte, a primeira implicação no domínio da educação poderia ser a de permitir ao aluno, seja em que nível do ensino for, estabelecer um real contato com os problemas importantes da sua existência, de modo a distinguir os problemas e as questões que pretende resolver. (ROGERS, 1999, p.330).

No início de 2014 surgiu a primeira oportunidade de assumir como professor titular uma turma de filosofia, todavia, em outra unidade escolar. Passei a lecionar em outra escola estadual, situada no mesmo município. Os desafios aqui eram outros e bem maiores que os anteriores. Eram quatro turmas de ensino médio no total, duas salas de primeiro ano e duas do segundo ano. Para ambas as turmas havia escassez de material didático. Haviam poucos livros didáticos, e por este fato, fiquei responsável por organizar o rodízio dos livros. Este não era o único obstáculo.

Encontrei as turmas de segundo ano inteiramente desestimuladas. Os próprios alunos descreviam uma experiência traumatizante com as aulas de filosofia no ano anterior, resultado de uma aprendizagem mecânica. Não havia estímulo para aprendizagem. Com estas turmas, os meus esforços não foram apenas apresentar os conteúdos propostos, mas os primeiros esforços se deram na tentativa de promover a compreensão da finalidade do aprendizado.

[...] o aluno constrói significados relativos aos conteúdos escolares como resultado de uma dinâmica interna própria, mas a natureza cultural dos conteúdos marca a direção na qual esse processo deve ser orientado a partir do exterior, através da intervenção do professor. $O$ aluno é o responsável final pela sua aprendizagem ao atribuir significado aos conteúdos, mas é o professor quem, com a sua intervenção, determina que as atividades das quais o aluno participa possibilitem uma orientação adequada do processo de construção, assim como um maior ou menor grau de amplitude e profundidade dos significados construídos. (COLL, 1998, p.78). 
Já com as turmas de primeiro ano, os esforços principais se deram na criação de subsunçores. Os alunos ingressantes do ensino médio, já dispunham de uma base de conhecimento em disciplinas que estavam presentes em boa parte da sua trajetória escolar, como as disciplinas de português e matemática. Porém, é um tanto quanto conflituoso para os alunos, chegar ao novo ciclo escolar e encontrar um significado para uma disciplina inteiramente nova. Então, dediquei meus esforços na construção de fortes subsunçores, para promover uma aprendizagem significativa. A produção de histórias em quadrinhos (HQ's) foi a ferramenta escolhida.

Figura 8 - Produção de hq's - mito de atlas

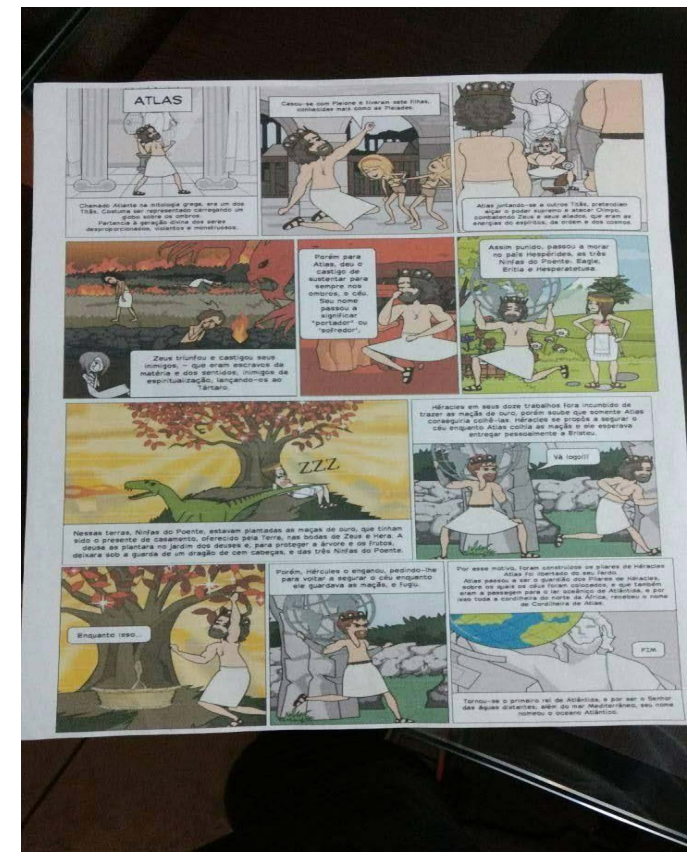

Figura 9 - Produção de hq's - mito de atena

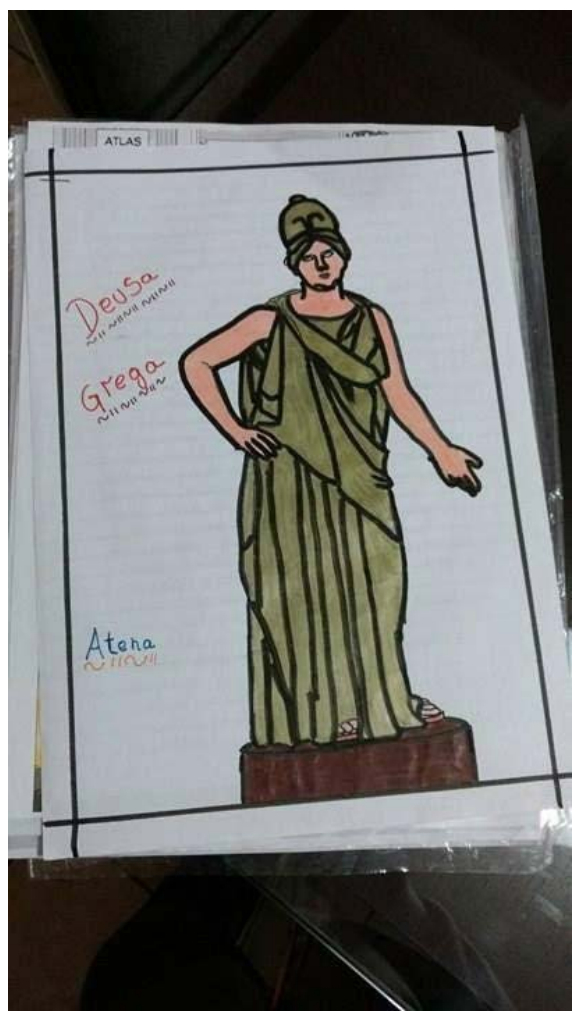


A proposta curricular previa que trabalhássemos em sala de aula com o eixo "A Filosofia e outras formas de conhecimento: mito, senso comum, ideologia, religião, arte, ciência”. Não obstante, parecia uma tarefa bem complicada conseguir com que os alunos entendessem de modo efetivo a distinção entre o caráter do pensamento mítico e a filosofia. Doravante, após uma aula expositiva sobre a definição e as características do mito, propus à sala que se dividissem em duplas, escolhessem um mito grego e a partir disto, produzissem uma história em quadrinhos retratando o mito e posteriormente realizassem uma breve apresentação para a turma.

O objetivo principal aqui, não era apenas que os alunos conhecessem as narrativas, mas sim que conseguissem visualizar na produção proposta, todas as características presentes no mito. A atividade foi um sucesso, todos os alunos participaram diretamente das produções das HQs, e mais do que isso, conseguiram compreender de modo claro e distinto aquilo que lhes fora proposto. Com a apropriação desses subsunçores, o aprendizado dos conceitos seguintes as características do pensar filosófico e a definição de filosofia - foram facilmente absorvidos.

Em junho de 2014, concomitante as aulas na escola estadual, passei a lecionar em um colégio particular, instituição que leciono até hoje. Nesta unidade de ensino, não há problemas de falta de estrutura. O desafio que agora se apresentava a mim eram: $O$ ensino de filosofia no ensino fundamental e no ensino médio, o sistema de ensino adotado pela instituição.

A disciplina de filosofia está presente na proposta curricular do colégio a partir do $6^{\circ}$ ano do ensino fundamental II. Quando fui convidado para assumir as turmas de ensino fundamental, em um primeiro momento me assustei. Lecionar filosofia para turmas do ensino médio já é um tanto quanto complexo, pensar na mesma atividade para o ensino fundamental, representou uma grande insegurança para mim. Foi preciso repensar as formas de abordagem do conteúdo. Optei em adotar uma sequência didática baseada em "eixos temáticos", objetivando abordar questões do universo dos alunos. Em inúmeros momentos as aulas dispõem de um caráter lúdico e o diálogo permanente com as linguagens artísticas, são ferramentas importantes no processo de ensino aprendizagem.

Nas turmas do ensino médio, o sistema de ensino adotado pelo colégio representa um grande desafio para a aprendizagem significativa. O material escolhido inteiramente apostilado, junto ao grande número de exercícios, poucas aulas semanais, as inúmeras avaliações (internas e externas) e muitos prazos a cumprir, caminham muito próximos de uma temida aprendizagem mecânica.

As ações que tenho tomado para promoção da aprendizagem significativa, consistem basicamente na promoção do processo de ensino aprendizagem e não arbitrários, além de exercer fomentar dentro do espaço escolar condições facilitadoras para o aprendizado. Conforme poderemos constatar através do relato de uma estudante do segundo ano do ensino médio, as aulas de filosofia têm disposto de um caráter significativo.

A disciplina de filosofia é bem extensa e cansativa, mesmo que para a maioria a matéria seja de difícil entendimento, você tenta explicá-la de um jeito que todos entendam. O método que utiliza, o de relacionar o conteúdo com algo que presenciamos no nosso cotidiano. Entender as meditações de Descartes, ou o mito de 
caverna de Platão sem usar o seu método de comparar com o nosso dia a dia, não seria tão fácil como foi. E acredito que, caso eu me torne professora de filosofia um dia, com certeza usarei esse método com os meus alunos. (Aluna do $2^{\circ}$ Ano Ensino Médio).

Toda experiência que vivenciei enquanto bolsista do PIBID, certamente foram fundamentais em minha construção e na práxis enquanto docente. Os impactos do programa se manifestam efetivamente, no dia a dia, dentro de sala de aula, nas aulas em que tenho o privilégio de ministrar.

Nosso principal papel como professores, na promoção de uma
aprendizagem significativa, é desafiar os conceitos já apren-
didos, para que eles se reconstruam mais ampliados e consis-
tentes, tornando-se assim mais inclusivos com relação a novos
conceitos. Quanto mais elaborado e enriquecido é um conceito,
maior possibilidade ele tem de servir de parâmetro para a cons-
trução de novos. Isso significa dizer que quanto mais sabemos,
mais temos condições de aprender. (SANTOS, 2013, p. 66).

Ao preparar uma aula, minha preocupação não se limita apenas em pensar em maneiras de expressar o conteúdo de modo claro, mas também em tentar encontrar um possível ponto de intersecção entre a realidade do educando e o conteúdo proposto, algo que aprendi de modo prático enquanto participante do PIBID, pois a todo instante, somos estimulados a produzir mecanismos e ferramentas que facilitem o processo de ensino-aprendizagem.

\section{Considerações Finais}

O ambiente escolar na contemporaneidade, com gratas exceções, não se manifesta como um ambiente que fomenta aprendizagem significativa. Resultado da crescente visão tecnicista no tocante ao processo de ensino-aprendizagem, o panorama que contemplamos diariamente nas salas de aula, é distante do ideal. A escola atual não tem obtido êxito na formação de alunos capazes de compreender o mundo, tampouco, integrá-lo na sociedade de modo que ele possa participar de forma crítica (COLL, 1998, p.77-78). Doravante, neste trabalho procuramos demonstrar como o PIBID/Filosofia - Mackenzie tem proporcionado subsídios para o ensino de filosofia significativo.

A aprendizagem significativa só ocorre a partir do instante que o educando passa a enxergar um sentido naquilo que aprende. Para que ela concretize, é necessário que exista um movimento de fora para dentro, entre o aprendiz em relação ao objeto a ser aprendido. Na visão ausubeliana, este movimento é fundamental estimular a ancoragem dos conteúdos aprendidos. Rogers, aponta que esse movimento é proveniente do interesse do aluno em função do êxito de seus anseios pessoais. Já para Coll, o que se relaciona a este movimento, é a intenção do educando em aprender. Neste sentido, o PIBID tem se 
colocado como um diferencial no processo ensino-aprendizagem, pois se coloca como um programa que atende aos três grandes eixos no que tange à educação: ensino, pesquisa e extensão - eixos que puderam ser facilmente observados ao longo deste trabalho.

No caso do PIBID/Filosofia/ Mackenzie/Capes, pudemos perceber através da exposição das intervenções realizadas pelos bolsistas em conjunto com os professores supervisores, a proposta de utilizar a sensibilização estética como instrumento de ensino-aprendizagem, proporciona aos educandos a aquisição de novos significados.

\section{Referências}

AUSUBEL, David Paul, NOVAK, Joseph e HANESIAN, Helen. Psicologia educacional. Rio de Janeiro: Interamericana, 1980.

BRASIL. Decreto $n^{0} 7.219$, de 24 de junho de 2010. Dispõe sobre o Programa Institucional de Bolsa de Iniciação à Docência - PIBID e dá outras providências. Diário Oficial da União. Brasília: Casa Civil da Presidência da República, 2010.

BRASIL. Ministério da Educação, Secretaria da Educação, Mídia e Tecnologia. Parâmetros Curriculares Nacionais: ensino médio. Brasília: Ministério da Educação, 1999. Disponível em: http://portal.mec.gov.br/seb/arquivos/pdf/cienciah.pdf. Acesso abrl2017.

CILENTO et all. Revisitando A Trajetória Do Pibid: Potencializando Saberes E Práticas Docentes No Curso De Filosofia Da Universidade Presbiteriana Mackenzie. Texto a ser apresentado no III Encontro Nacional do PIBID|Filosofia em Natal - RN, em junho de 2017.

COLL, César, EDWARDS, Derek. Ensino, aprendizagem e discurso em sala de aula: aproximações ao estudo do discurso educacional em sala de aula. Porto Alegre: Artmed, 2003.

FREIRE, Paulo. Pedagogia do Oprimido. Rio de Janeiro: Editora Paz e Terra, 1987. MOREIRA, M.A. A teoria da aprendizagem significativa e sua implementação em sala de aula. Brasília: Editora da UnB. 1999.

MOREIRA, Marco Antônio; MASINI, Elcie F. Salzano. Aprendizagem Significativa: a teoria de David Ausubel. São Paulo: Editora Moraes, 1982.

REVISTA PANDORA BRASIL. Os impactos do Pibid na Universidade: uma experiência de criação de material didático pedagógico na disciplina Oficina de Práticas Pedagógicas I. São Paulo, n 66. Agosto, 2015. Disponível em: http://revistapandorabrasil.com/ revista_pandora/edicao66.htm. Acesso em maio/2017.

ROGERS, C. Tornar-se pessoa. São Paulo: Martins Fontes, 1999.

SANTOS, Júlio César Furtado dos. Aprendizagem significativa: modalidade de aprendizagem e o papel do professor. Porto Alegre: Editora Meditação, 2013. 
SANT'ANNA, Flávia Ma. Microensino e habilidades técnicas do Professor. São Paulo, McGraw-Hill do Brasil, 1979.

SEVERINO, Antonio Joaquim. Formação política do adolescente no Ensino Médio: a contribuição da Filosofia. In: Pro-Posições, Campinas, v. 21, n. 1 (61), p.57-74, jan./abr. 2010.

\section{Correspondência}

Felipe Barreto Santana - Rua Francisca Roncada Parolise, 59, Jardim Wanda, Complexo Educacional Taboão da Serra, CEP 06.765-470, Taboão da Serra, São Paulo, Brasil.

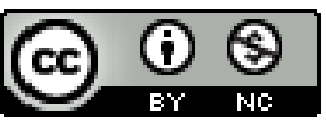

This work is licensed under a Creative Commons Attribution-NonCommercial 4.0 International (CC BY-NC 4.0) 